\title{
Nutritional and sensory attributes of soy-supplemented cereal meals
}

\author{
Alabi M.O ${ }^{1}$ and Anuonye J.C. ${ }^{2}$ \\ ${ }^{1}$ Hotel and Catering Department, Federal Polytechnic, Bida, Niger State \\ ${ }^{2}$ Oilseeds Research Programme, National Cereals Research Institute, Badeggi, Niger State \\ Address for correspondence: Email: MOGAlabi@yahoo.com
}

ABSTRACT

\begin{abstract}
Soy flour, cereal flour and starch were prepared with slight modifications of the traditional methods. Cereal starch and flour were then fortified with soy flour in a ratio of $3: 1$ (w/w) of cereal starch flour to soy flour and were used to prepare dumplings breakfast meals and cakes. Unfortified meals were prepared as control samples. Sensory analysis and proximate composition of both fortified and unfortified samples were determined. The results showed that the acceptability of fortified samples were over $60 \%$ in all
\end{abstract}

parameters tested. Proximate composition indicated increases of $100 \%$ in the protein content of fortified meals with concomitant decreases in carbohydrate content. The fortification of these catering products is one sure way of improving the nutritional status of many in our society.

Key words: Soy flour, cereal flour, starch, supplement, dumplings.

\section{INTRODUCTION}

$\mathbf{P}$ rotein in human diet is received from several sources that include cereals vegetables root crops legumes meat egg milk and fish. Of all these; sources from animals are regarded as the best because of its amino-acid content (Alabi et. al., 2001). However, the cost of animal protein is increasing everyday, thus making it unavailable for the low and some average income groups. The unavailability has resulted into looking for other alternatives. The next chosen alternatives are legume proteins. Of these legumes, soybean have been found by many researchers to have combine favourably well with cereals that is rich in sulphur containing amino-acid (Alabi, et al., 2001). The potential of soybean for food fortification has been documented (Uwaegbute et al., 1998, Badifu and Anuonye 1998).

Soybean (Glycine max (L) Merrill) belongs to the family leguminoisae and sub-family papilionnideae. It is a remarkable source of protein for both animals and human consumption and is also a leading source of edible oils and fats (Singh and Rachie, 1986). As an important component crop, soybean is being used in various traditional farming systems of various countries. It has been used commonly in Southern Kaduna State, Benue State and the Federal Capital Territory of Nigeria in Inter cropping with cereals such as sorghum (Anon, 1992).

In Nigeria today, Soybean is being used in various ways in different homes as soymilk, soyogi, soy-daddawa, soy-akara, soy-gari, soy-soup, and hot soy-drink. Escalating prices of protein rich foods continue to force greater percentage of the populace, to eat food supplying less of the required dietary nutrient. Due to expanding economy and urbanization, catering services continues to expand. The catering industry therefore stands to play a major role in the provision of adequate nutrition for the teeming 
populace due to its unique position in meeting the daily food need of different cadres of people in the society living in urban and semi-urban areas, villages and hamlets. Catering services therefore remain major features of our society. In the Middle Belt Zone, cereal based meals (dumplings, breakfast meals and snacks) are the prominent meals served in majority of eatinghouses. The nutritional status of these meals can be greatly enhanced by incorporation of soybean (Anuonye et al., 1994). This work was therefore undertaken to:

(i) Evaluate the acceptability of soy-fortified dumplings and breakfast meals for the catering Industry.

(ii) Formulate acceptable recipe standard for soycake preparation

(iii)Create awareness on utilization of soy-flour for food formulation in the catering Industry.

\section{MATERIALS AND METHODS Preparation of Soy flour}

Homemade soy-flour was produced from (TGM-579) obtained from the seed store of the National Cereals Research Institute Badeggi.

Soy-flour and starch processed as shown in Fig. 1 and 2 respectively. Soybean was sorted and thoroughly washed in clean tap water and then sun dried for 3 - 4h. The tempered seeds were then cracked in an attrition mill.

Soybean hulls were removed by winnowing. The seed particles were then washed in cold tap water until foaming ceased. The washed particles were then soaked in cold tap water enough to submerge the particles for about $17 \mathrm{~h}$ (overnight). The particles were then washed in cold tap water and boiled for $5 \mathrm{mins}$. Washed particles were then drained and spread on clean laboratory table to dry at ambient temperature $23 \pm 5^{\circ} \mathrm{C}$ for about 17h. The dried seed particles were milled in an Attrition Mill into flour and then sieved with a commercial sieve.
Preparation of dumpling and breakfast meals

Soy fortified dumplings and breakfast meals were prepared by mixing soy-flour with cereal flour/starch in a ratio of 1:3 (w/w) respectively according to the methods of Anuonye et al., (1994). The mixture was then sieved with a commercial sieve $1 \mathrm{~mm}$ and then slurred in one part of water to five parts of flour before cooking in boiling water $\left(90 \pm 10^{\circ} \mathrm{C}\right)$ for the dumplings. The meal was continuously stirred to a firm consistency. For the breakfast meals, boiling water at $\left(90 \pm 10^{\circ} \mathrm{C}\right)$ was poured on the slurry and the gelatinized starch was stirred to uniform consistency.

\section{Formulation of recipe for the preparation of} Soy cake

For soy cake, basic recipe for cake made from wheat flour was used. The cakes were formulated as shown below:

Sample

(i) $100 \%$ wheat flour cake (control)

(ii) $100 \%$ soy flour cake

(iii) $75 / 25 \%$ wheat/ soy flour cake

(iv) $65 / 35 \%$ wheat/ soy flour cake

(v) $50 / 50 \%$ wheat/ soy flour cake

The cakes were creamed and baked according to Ceserani and Kinton (1981).

Sensory analysis of prepared dumpling and breakfast meals

The dumplings, breakfast meals and the cakes were subjected to sensory panels using a 5-point Hedonic scale according to Watts et al (1989) with a scaling range of 1 to 5 ( $1=$ Like extremely, 3 = Neither like nor dislike and $5=$ Dislike extremely).

\section{Statistical analysis}

Samples with significant means were separated using the Least Significant Difference (LSD) according to Ihekoronye and Ngoddy (1985). 


\section{Proximate Analysis}

Proximate composition of samples was determined according to AOAC (1980).

SOYBEANS

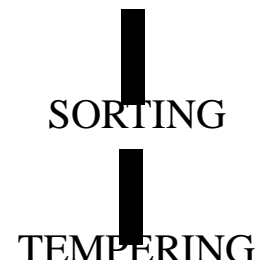

CRACKING

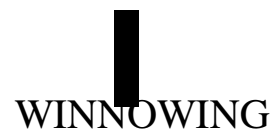

SOAKING (Overnight)

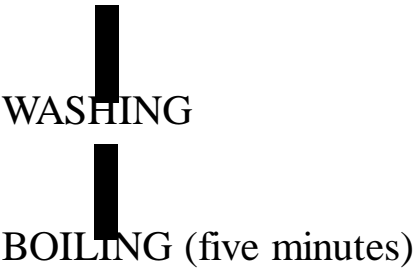

DRAINING

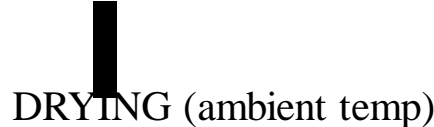

MILLING

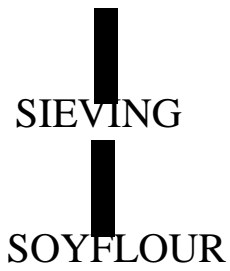

CEREAL GRAINS

SORIING/CLEANING

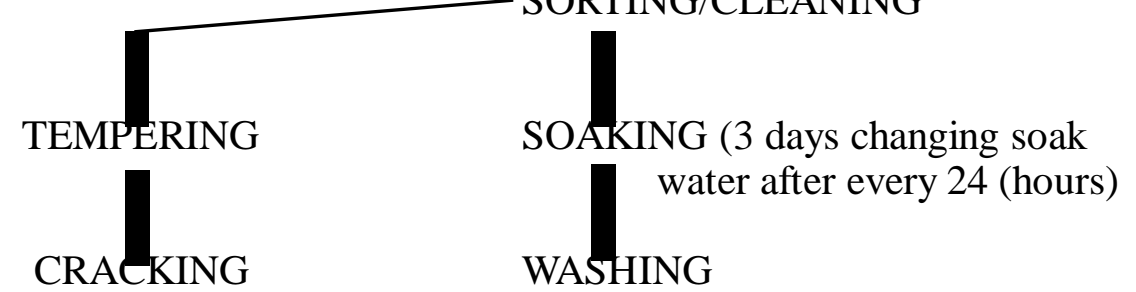

MILLING
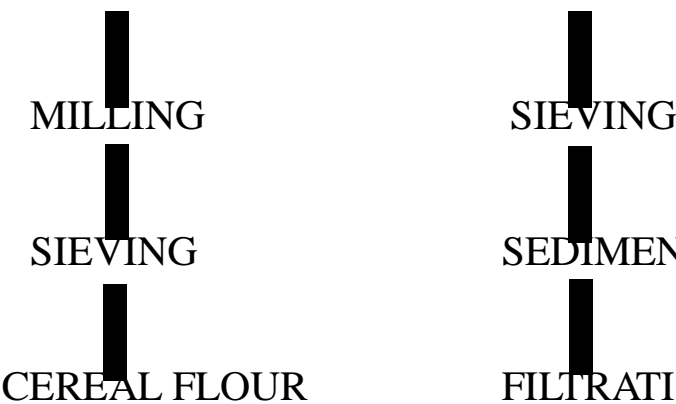

SEDIMENTATION

FILTRATION

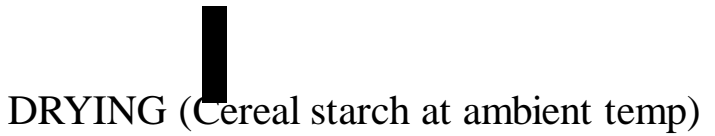

CEREAL STARCH

Figure 1: Flow chart for preparation of Soy flour with enhanced white color appeal 
Figure 2: Flow chart for the Preparation of Cereal Starch/Cereal flour

\section{RESULTS AND DISCUSSION}

Organoleptic assessment of the dumplings (Table 1) showed that in all the parameter tested (colour, mouth, flavour, taste, odor, texture and overall acceptability) there was no significant $(\mathrm{P}<0.05)$ difference in preference of the control to soy-fortified samples. This pattern of results was obtained for the breakfast meals (Table 2). The results showed that addition of soy-flour at $25 \%$ levels to cereal starch/flour had no adverse effect to the sensory attributes as well as the rheological behaviors of the cereal starch(es). The results suggested that the processing given the soybean was adequate in checking the beany flavors associated with soybeans. Whole wheat cake recorded a significant preference to soy/ wheat cake in all ratios except in the 3:1 ratio. Table 3 showed that 9 out 10 of panelist preferred the whole-wheat cake with the same level of preference for the soy/wheat cake of 3:1 ratio. Though this level of preference as recorded was significant 7 out of 10 panelists still found the wheat/soy cake acceptable at the 2:1 and 1:1 ratios. The discrepancy in preference of the cake with $25 \%$ soybean flour showed that beyond this level of incorporation of soyflour unacceptable soy/wheat cake may result. This result is in agreement with the findings of Greenberg and Harting (1998), who reported that addition of soyflour to cereals for baking should be at $20 \%$. However, the results of this study show that soyflour beyond $20 \%$ can still produce acceptable soy/wheat cake. Comparing the whole wheat cake and the $25 \%$ fortified wheat flour cake, the results showed that there was no significant difference in all parameters tested, (colour, mouth, flavour, taste, odor texture and overall acceptability) except in texture. The difference in texture must have been as a result of the increase protein arising from the added soybean. It was observed that the fortified wheat cake was softer than the whole-wheat cake known to the panelists. These findings are in agreement with those of Ogundipe (1987). 
Table 1: Sensory evaluation of fortified and unfortified soy/cereal dumplings

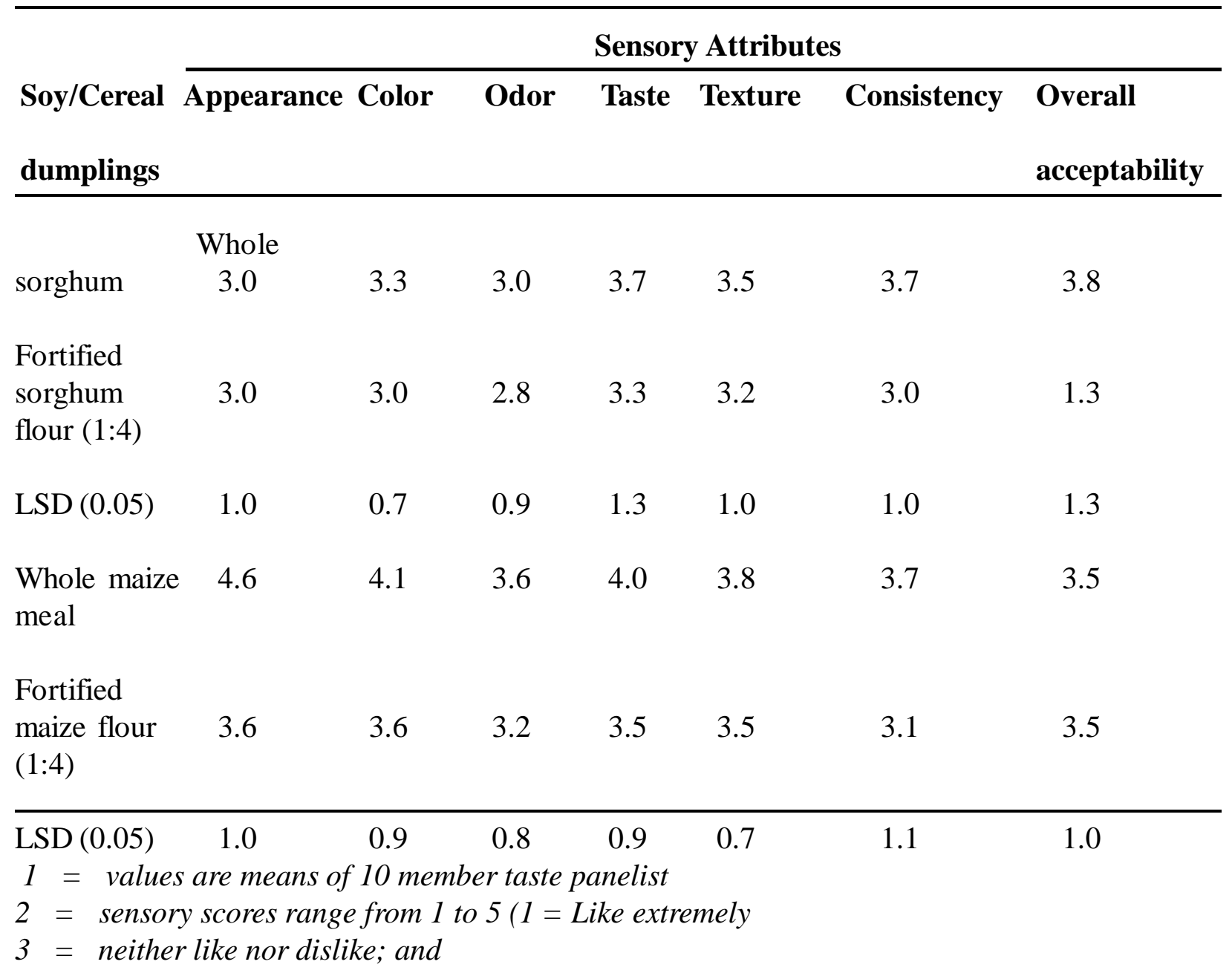


Table 2: Sensory evaluation of fortified and unfortified soy/cereal meals

\begin{tabular}{|c|c|c|c|c|c|c|c|}
\hline \multirow[b]{2}{*}{$\begin{array}{l}\text { Soy/Cereal } \\
\text { dumplings } \\
\text { acceptability }\end{array}$} & \multicolumn{7}{|c|}{ Sensory Attributes } \\
\hline & Colour & $\begin{array}{l}\text { Mouth } \\
\text { feel }\end{array}$ & Flavor & Taste & Odor & Texture & Overall \\
\hline $\begin{array}{l}\text { Whole } \\
\text { maize } \\
\text { meals }\end{array}$ & 4.0 & 3.0 & 3.4 & 3.4 & 3.0 & 3.3 & 4.0 \\
\hline $\begin{array}{l}\text { Fortified } \\
\text { maize } \\
(1: 4)\end{array}$ & 4.0 & 4.0 & 4.0 & 4.0 & 4.0 & 4.0 & 4.0 \\
\hline $\operatorname{LSD}(0.05)$ & 4.0 & 4.0 & 5.0 & 7.0 & 4.0 & 3.3 & 4.0 \\
\hline $\begin{array}{l}\text { Whole } \\
\text { millet } \\
\text { meals }\end{array}$ & 4.0 & 3.0 & 3.1 & 3.0 & 3.3 & 3.0 & 3.0 \\
\hline $\begin{array}{l}\text { Fortified } \\
\text { sorghum } \\
\text { meals }(1: 4)\end{array}$ & 4.0 & 3.4 & 3.4 & 4.0 & 4.0 & 4.0 & 4.0 \\
\hline LSD (0.05) & 4.0 & 4.0 & 5.0 & 7.0 & 4.0 & 3.3 & 4.0 \\
\hline $\begin{array}{l}\text { Whole } \\
\text { sorghum } \\
\text { meals }\end{array}$ & 3.6 & 4.0 & 4.0 & 3.8 & 3.0 & 3.0 & 4.0 \\
\hline $\begin{array}{l}\text { Fortified } \\
\text { sorghum (1:4) }\end{array}$ & 3.4 & 4.0 & 4.0 & 3.4 & 3.4 & 4.5 & 4.0 \\
\hline $\operatorname{LSD}(0.05)$ & 3.0 & 5.0 & 4.0 & 8.0 & 7.0 & 3.3 & 7.0 \\
\hline $\begin{array}{l}1=\text { values ar } \\
2=\text { sensory } \\
3=\text { neither } l \\
5=\text { dislike ex }\end{array}$ & $\begin{array}{l}\text { means of } \\
\text { ores rang } \\
\text { e nor dist } \\
\text { emely) }\end{array}$ & $\begin{array}{l}\text { membe } \\
\text { rom } 1 \text { to } \\
\text {; and }\end{array}$ & $\begin{array}{l}\text { te pane } \\
=\text { Like }\end{array}$ & tremely & & & \\
\hline
\end{tabular}


Table 3: Sensory evaluation of fortified and unfortified soy cake

\begin{tabular}{lcccc}
\hline \multirow{2}{*}{ Soy cake } & \multicolumn{3}{c}{ sensory qualities } \\
\cline { 2 - 5 } $\begin{array}{l}\text { Wheat flour } \\
\text { cake (control) }\end{array}$ & $4.4 \mathrm{a}$ & $4.4 \mathrm{a}$ & $4.5 \mathrm{a}$ & $4.7 \mathrm{a}$ \\
$\begin{array}{l}\text { Soy flour } \\
\text { cake }\end{array}$ & $3.4 \mathrm{~b}$ & $3.4 \mathrm{~b}$ & $3.3 \mathrm{~b}$ & $3.3 \mathrm{c}$ \\
$\begin{array}{l}\text { Wheat soy } \\
\text { flour cake (3:1) }\end{array}$ & $4.3 \mathrm{a}$ & $4.3 \mathrm{a}$ & $4.1 \mathrm{~b}$ & $4.3 \mathrm{ab}$ \\
$\begin{array}{l}\text { Wheat soy } \\
\text { flour cake (2:1) }\end{array}$ & $3.9 \mathrm{ab}$ & $3.9 \mathrm{ab}$ & $3.4 \mathrm{~b}$ & $3.8 \mathrm{~b}$ \\
$\begin{array}{l}\text { Wheat soy } \\
\text { flour cake (1:1) }\end{array}$ & $3.7 \mathrm{~b}$ & $3.7 \mathrm{~b}$ & $3.4 \mathrm{~b}$ & $3.8 \mathrm{c}$ \\
\hline
\end{tabular}

Means with a common alphabet in the same column are not significantly different $(p<0.05)$.

$1=\quad$ values are means of 10 member taste panelist

2 = sensory scores range from 1 to $5(1=$ Like extremely

3 = neither like nor dislike; and

5 = dislike extremely)

and Alabi and Oluwatosin (2001) in their endeavors to develop soybean recipes for common daily meal of the rural populace.

The proximate composition of the dumplings and breakfast meals are shown in Table (4) and (5) respectively. The sensory evaluation results were in agreement with the trypsin inhibitor and tannin analysis (Table 4). The very low level of trypsin inhibitor activity and trace amounts of tannin was indicative that the processing given the soybean was adequate in reducing the trypsin inhibitor activity and tannin levels. None of the panelist complained of the grassy after flavor of soybean. In all cases, the protein, fat and ash increased with corresponding decreases in moisture and carbohydrate. This was expected and is in agreement with literature report Iwe and Onuh (1992). According to Iwe and Onuh, (1992), two feedings of either meal at $50 \mathrm{~g}$ would yield over $20 \%$ protein and about $1890 \mathrm{k} / \mathrm{cal}$ energy.

According to Greenberg and Harting (1998) consumption of $17-25 \mathrm{~g}$ of soy protein a day reduces serum cholesterol to $9.3 \%$ on the average. Also low-density lipoprotein cholesterol (LDL) reduces to about $13 \%$ while the highdensity lipoprotein (HDL) cholesterol may not be affected. It is therefore clear that by eating 
$25 \mathrm{~g}$ of soyprotein a day the chances of falling victim to heart diseases are almost reduced to one-thirds. Nursing mothers with infants allergic to cow milk will find the soy-cereal breakfast meal an alternative (Greenberg and Harting 1998). The lowered moisture content indicates that the composite flours could be stored at ambient temperatures Soluski et al., (1980).

Table 4: Proximate composition of fortified and unfortified soy/cereal dumplings

\begin{tabular}{llllll}
\hline $\begin{array}{l}\text { Soy/Cereal } \\
\text { Dumplings }\end{array}$ & Moisture(\%) & Fat(\%) & Protein(\%) & Ash(\%) & Carbohydrate(\%) \\
\hline $\begin{array}{l}\text { Whole maize } \\
\text { meal }\end{array}$ & 10.0 & 0.3 & 10.0 & 0.3 & 79.4 \\
$\begin{array}{l}\text { Fortified } \\
\text { Maize Meal }\end{array}$ & 9.0 & 0.9 & 25 & 0.8 & 64.30 \\
$\begin{array}{l}(1: 4) \\
\text { Whole }\end{array}$ & 4.6 & 4.1 & & & \\
$\begin{array}{l}\text { Sorghum } \\
\text { meal }\end{array}$ & & 10.0 & 4.0 & 3.6 \\
$\begin{array}{l}\text { Fortified } \\
\text { Sorghum } \\
\text { meal (1:4) }\end{array}$ & 3.6 & 3.6 & 23.0 & 3.5 & 3.5 \\
\hline
\end{tabular}


Table 5: Proximate composition of fortified and unfortified soy/cereal break fast meals

\begin{tabular}{|c|c|c|c|c|c|c|c|}
\hline $\begin{array}{l}\text { Soy/Cereal } \\
\text { Breakfast }\end{array}$ & $\begin{array}{l}\text { Moisture } \\
(\%)\end{array}$ & $\begin{array}{l}\text { Fat } \\
(\%)\end{array}$ & $\begin{array}{l}\text { Protein } \\
(\%)\end{array}$ & $\begin{array}{l}\text { Ash } \\
(\%)\end{array}$ & $\begin{array}{l}\text { Carbohydrate } \\
(\%)\end{array}$ & $\begin{array}{l}\text { Trypsin } \\
\text { inhibition }\end{array}$ & $\begin{array}{l}\text { Tanin } \\
(m g / \%\end{array}$ \\
\hline meals & & & & & & $(\%)$ & \\
\hline $\begin{array}{l}\text { Whole } \\
\text { maize } \\
\text { meals }\end{array}$ & 9.5 & 0.2 & 9.5 & 0.3 & 80.5 & Trace & Trace \\
\hline $\begin{array}{l}\text { Fortified } \\
\text { maize }\end{array}$ & 9.0 & 0.3 & 22.0 & 1.2 & 67.4 & Trace & Trace \\
\hline$(1: 4)$ & & & & & & & \\
\hline $\begin{array}{l}\text { Whole } \\
\text { millet } \\
\text { meals }\end{array}$ & 11.3 & 0.2 & 9.7 & 0.3 & 78.5 & & \\
\hline $\begin{array}{l}\text { Fortified } \\
\text { millet } \\
(1: 4)\end{array}$ & 9.7 & 0.3 & 27.2 & 1.2 & 61.1 & & \\
\hline $\begin{array}{l}\text { Whole } \\
\text { sorghum } \\
\text { meals }\end{array}$ & 11.3 & 0.1 & 10.1 & 0.6 & 77.9 & & \\
\hline Fortified & & & & & & & \\
\hline
\end{tabular}




\section{CONCLUSION}

From the results presented, it is concluded that addition of soyflour to cereal flour/starch enhanced the nutritional composition of these meals. It is already known that mixtures of legume and cereals are complementary resulting in balance of the essential amino acids needs of the body. It is therefore clear that adoption of this simple technology by catering homes will result in serving of better protein enriched meals and snacks to the ever increasing number of customers. Since soy flour is free from cholesterol and other cardiac arrest-inducing substances, nutritional health hazards associated with consumption of animal fats are not only minimized but also scarce resources are saved from hospital expenses. The customer may however pay slightly more due to the food enrichment that is advantageous.

\section{REFERENCES}

Alabi, M.O., Anuonye, J.C., Ndaeji, C.F. and Idowu, A. A.(2001). Comparison of the growth and development of selected children in soybean and non soybean producing and utilization villages in Niger State, Nigeria. Poly Math Journal,.Vol 2, No1, p 8-12.

Alabi M.O. and Oluwatosin, B.C. (2001). Creating Awareness on utilization of Soybean flour for baked products in the catering industry; A preliminary study of soy cake, physical properties and acceptability. Unpublished.

Anon, (1992). Nigerian Soybean Association. Tropical oilseed journal production, processing and utilization.

Anuonye, J.C., Ndaeji, C.F. and Osho, S.M. (1994) Fortification of indigenous staple foods in Nigeria with soy flour. Paper delivered at the Nigerian Soybean Association conference in Kawo, Kaduna.
AOAC, (1984). Official Methods of Analysis, 14th Edition, Association of official Analytical Chemists. Washington D.C.

Badifu, G.I.O., and Anuonye, J.C. (1998). Development and stability of spiced soy-millet flour. For the Preparation of "soy-kunuzaki. A non-alcoholic Beverage. Journal of Applied Science and Management, Vol 2, 93 - 97.

Cesareni, V and Kinton R (1980). Practical cookery, Fourth edition

FAO, (1998) "Food and Nutrition in the Management of group Feeding Programmes". FAO and Nutrition. Paper 23 Rev. 1. p 150-157.

Greenberg, P. and Harting, H. (1998). "The whole soy cook book". Three Rivers Press, New York. p.17

Ihekoronye, A.O and Ngoddy, P.O. (1985). "Integrated food science and technology for the tropics". Macmillan Publishers.

Iwe, M.O. and Onuh J.O., (1992). Functional and Sensory properties of soybean and sweet potato flour mixtures. Lenbenson, Wens UTechnol. p. $569-573$.

Ogundipe, P. E. (1987). The role of Soybean in sustainable agriculture in Africa. In the proceedings of the Global Workshop1991. Africa's Agricultural Development in the 90's: Can it be sustained? Arusha, Tanzania, 15-17 May.

Singh, S.R. and Rachie, K.O. (1986). Soybean for the tropics. Research production, processing and utilization. p15

Uwaegute.A.C.,Osho, S.M. and Obatolu, V.A. (1995). Acceptability and chemical evaluation 
of fortified yam (Dioscorea Spp) products. Watts, B.M., Ylimaki, G.L. Jeffery, L.E. and In:Postharvest technology and commodity Ekics, L.G. (1989.) Basic sensory methods for Marketing. Edited by RSB Ferris. IITA, lbadan. food evaluation. International Development p. $172-178$. Research Centre, Ottawa, Ontario, Canada. p. 6879. 